furnish the same class of remains as those found outside. The personal ornaments are the most worthy of note. Besides bronze harp-shaped brooches of the common late Roman type, there were two in gilt-bronze, of a sigmoid shape, and adorned with a singularly beautiful pattern in blue, yellow, red, and green enamel. They are undoubtedly of a style purely Celtic. A harp-shaped brooch, Roman in design, is adorned with a most delicate pattern in blue and red enamel. Among the other brooches, one small oblong enamel is of a form hitherto unknown in brooches of this date, while a second consists of a small disc of bronze, with a plate soldered to it bearing a flamboyant ornament of Celtic design. There were also bronze gilt armlets. The whole evidence furnished by the personal ornaments in a word points to their Romano-Celtic origin, and it is not improbable that the principal seat of the art of enamelling was Yorkshire, the few enamels of that particular kind which have been found occurring, with one or two exceptions, in that county. The date of the occupation is shown by the coins, which range from Trajan down to the barbarous imitations of the coins of Tetricus. The latter were in circulation in the fourth and fifth centuries, and probably continued to be used in that portion of the Romano-Celtic kingdom of Strathclyde down to its final conquest by Eadberht in 756 A.D. The whole group of remains is precisely of the same character as those found around the ruins of Roman villas in Britain, and has probably been introduced by Romano-Celtic in habitants who fled from their luxurious homes to take refuge from the ravages of the Picts or Scots, or of the Northumbrian Angles, who were pressing on that portion of the frontier of Strathclyde during the 5 th, 6 th, and 7 th centuries. To suppose that people using articles of luxury such as those found in the cave would have chosen such an inclement abode, except under the pressure of necessity, is unreasonable.

At the entrance below the Romano. Celtic strata a layer of angular debris fallen from the cliff above, six feet thick, rested on a thick deposit of gray clay. At their point of junction a curious bone harpoon, a bone bead, the remains of red deer, horse and Celtic short-horn, and of bear, were found, which testified to the occupation of the cave by man long before the Romano-Celts used it as a refuge. The two flint flakes and two lumps of red ruddle found were probably obtained from this lower horizon, which, as the talus died away at the entrance of the cave, became confused inside with the Romano-Celtic stratum immediately above. It is probably of Neolithic age.

The grey clay underneath was homogeneous and very tenacious, and as the layer dipped away from the entrance, it must have been introduced by water flowing from the ravine into the cave. It was resolved to give up the attempt to fathom this bed of clay, after sinking a shaft twentyfive feet deep without any results.

The committee are desirous of exploring others of the many caves in the neighbourhood, if they can obtain support necessary to carry on a work which is of almost equal interest to the archæologist and to the historian.

\section{NEW SPECIES OF MADREPORE}

M R. W. SAVILLE KENT read a paper at a recent I meeting of the Zoological Society on various new species of Madrepores, or Stony Corals, met with by himself while engaged upon arranging, naming, and cataloguing the fine series contained in the British Museum. Among the more interesting of these, commencing with the family of Turbinolidæ, Mr. Kent drew attention to a fine species of Acanthocyathus from Japan, more closely allied to a Maltese Miocene form $(A$. Hastings $a)$ than to any known existing one; and also to a Flabellum allied to $F$. Anthobhyllites, whose most remarkable feature rests in the phenomena connected with its reproduction by the process of gemmation, which invariably results in the destruc- tion of the parent; the reproductive bud always originating within the margin of the parent calyx, which, in the course of its development, it splits to pieces. For this aberrant form Mr. Kent proposes the appropriate name of Flabellum matricidum. In the family of the Oculinidæ, which comprises the majority of the species introduced by Mr. Kent, are three new forms of Allopora, and numerous ones of Stylaster, Distichopora and Amphihelia, the first-named genus in particular containing a magnificent arborescent species, upwards of a foot in height, of a delicate rose colour, having a stem of such thickness and of such dense consistence that Mr. Kent is of the opinion that, if procurable in any quantity, it may eventually prove of high economic value, and even replace to some extent the well-known Corallizun rubrum. The examination of these new varieties has enabled $\mathrm{Mr}$. Kent to define more precisely the characters of Allopora, and its true distinctions from Stylaster, Distichopora, and other allied genera. In all, Mr. Kent introduces some twenty species as new to science.

\section{SUBTERRANEAN ELECTRICAL DIS- TURBANCES}

A FEW minutes before and after the earthquakes of the 17 th March last powerful positive electrical currents were rushing towards England through the two Anglo-American telegraph cables, which are broken near Trinity Bay, Newfoundland. Mr. C. F. Varley, C.E., who informed us of the fact, broaches the novel speculation that some earthquakes may be due to subterranean lightning. He imagines that as the hot centre of the earth is approached, a layer of hot dried rock may be found which is an insulator, while the red hot mass lower down is a conductor. If this conjecture be true--and there is plausibility in it-then the world itself is an enormous Leyden jar, which only requires charging to a very moderate degree to be equal to the production of terrific explosive discharges.

The French Atlantic cable was disturbed at the same time, and so were many of the English land-lines, but the only observations as to the direction of the current were made by means of the Anglo-American telegraph cables.

A number of Mr. Varley's charts about earth-currents were published in the Government Blue Book of I85960 , showing that the direction of these currents across England was in a very notable degree determined by the contour of the coast, and that the same auroral discharges would often produce currents at right angles to each other in direction, in different parts of Britain.

\section{NOTES}

A PROPOSAl has been made that;" certain Medical Schools on the north and south sides of the river should be amalgamated, in order that, by concentration of power, the teaching shall be made more efficient than it is at present, the teachers being able to devote themselves more unreservedly to their duties than they possibly can do under existing arrangements. The absolute necessity of some such arrangement as this is obvious.

MR. RUTHERFORD and M. Janssen, to whose labours cosmical physics owes so much, are both now in this country, the former, we regret to learn, in conseguence of a peremptory order to cease work for a time. At the last meeting of the Royal Astronomical Society, Mr. Rutherford exhibited his exquisite photograph of the Pleiades, which represents the last important outcome of celestial photography. It appears that M. Janssen's observatory for solar research, which had been erected in one of the pavilions of the Palace of St. Cloud, at the cost of the Emperor, was one of the first buildings to be entirely destroyed by the German fire. 